\title{
Magia, visão e ação
}

[Magic, vision, and action]

\section{Starhawk $^{\mathbf{x}}$}

Tradução de Adriana Rinaldi e Jamille Pinheiro Dias.

RESUMO - Culturas indígenas e antigas tradições espirituais centradas na Terra, vindas da Europa e do Oriente Médio, veem o mundo como relacional, como uma teia de vida interconectada. Essa percepção introduz perspectivas fundamentais para enfrentarmos as grandes crises de nosso tempo: colapso ambiental massivo em escala global, além da enorme disfunção social e política dele derivada. Precisamos de ferramentas e de uma visão clara de outras possibilidades para a cura de ecossistemas, de sistemas sociais e indivíduos, bem como de estratégias de organização, criação de redes e enfrentamento do poder. Baseando-se em sua ficção visionária e em décadas de trabalho dedicados à permacultura, ao ativismo e à espiritualidade centrada na Terra, Starhawk sugere como podemos levar adiante essa mudança. . PALAVRAS-CHAVE - Espiritualidade centrada na Terra; permacultura; vida interconectada; ativismo. • ABSTRACT · Indigenous cultures and ancient European and Middle Eastern earth-based spiritual traditions see the world as relational, as a web of interconnected life. That consciousness furnishes key understandings for approaching the great crises of our time: massive environmental on a global scale, and the massive social and political dysfunction that drives it. To heal, we need. We need tools and a clear vision of other possibilities for healing both ecosystems, social systems and individuals, and we need strategies for organizing, networking, and confronting power. Starhawk draws on her visionary fiction, and her decades of work in permaculture, activism, and earth-based spirituality to suggest how we can make this shift. • KEYWORDS · Earth-based spirituality; permaculture; interconnected life; activism.

Recebido em 20 de janeiro de 2018

Aprovado em I2 de março de 2018

STARHAWK. Magia, visão e ação. Revista do Instituto de Estudos Brasileiros, Brasil, n. 69, p. 52-65, abr. 2018.

DOI: http://dx.doi.org/Io.II6o6/issn.23I6-90IX.voi69p52-65

I Earth Activist Training (EAT, Cazadero, Califórnia, EUA). 
Algumas semanas atrás, em São Francisco, participei de uma grande manifestação em defesa da ciência, após as eleições de Donald Trump, com milhares de pessoas marchando pelas ruas. "A ciência é real! A ciência é real!", alguém começou a cantar. Quando percebi, muitos já cantávamos juntos. O que me ocorreu naquele momento foi: “em que época estamos? Seria 2017 ou I5I7?”. Como nos reduzimos a isso? Como chegamos ao ponto de marchar pela rua cantando "A ciência é real!"? Acredito que algumas das questões discutidas aqui na ReACT têm muito a nos dizer a respeito do motivo pelo qual chegamos a esse ponto.

Nos Estados Unidos, acredito que estamos vivendo uma situação em que grande parte da população não consegue de fato dizer mais o que é real. As pessoas estão extremamente confusas. Passam tanto tempo na internet recebendo uma infinidade de notícias falsas e contraditórias sobre todos os tipos de assunto que ninguém sabe ao certo o que está acontecendo. E se há uma coisa na qual os americanos (e uso o termo "americanos" coloquialmente, para me referir a pessoas dos Estados Unidos que compartilham uma determinada cultura de forma abrangente) acreditam em todos os setores da sociedade, independentemente de diferenças políticas, é que em algum lugar existe uma câmara secreta cheia de gente - gente que eles não sabem quem é - controlando o mundo. Isso torna as pessoas todas muito suscetíveis ao que aconteceu em nossas últimas eleições, nas quais uma imensa onda de desinformação proveniente de todos os tipos de fontes fez com que pessoas suficientes votassem em Donald Trump, impedindo que pessoas suficientes se posicionassem e votassem em outro alguém (ou que tivessem seus votos de fato contabilizados). É por acontecimentos assim que acabamos descendo a rua, um tanto desencorajados, cantando "a ciência é real!".

Se é assim, o que fazer a respeito? Acredito que primeiro precisamos compreender tanto o valor quanto as imperfeições da ciência. Além disso, conhecer um pouco de como a ciência veio a se tornar o que é, o que nos leva de volta ao território da magia. Se considerarmos que a ciência, segundo a maneira como a definimos, diz em grande medida respeito ao que é quantificável e mensurável (alegando que só podemos considerar real o que é quantificável e mensurável), talvez faça sentido contestar a afirmação de que "a ciência é real", já que ela é um método de averiguação do que é real - e não, na verdade, algo real em si. É como no caso da guerra ao terror: como guerrear contra um sentimento? 
O método científico envolve experimentos controlados nos quais uma variável é considerada e modificada; em seguida, o experimento é repetido e verificado. Esse método nos trouxe muitos benefícios; ele criou o mundo no qual vivemos hoje. Ele me permitiu chegar ao Brasil em um avião que se sustentou no ar e não caiu. Não queremos perder o modo de compreensão que esse método nos traz. No entanto, uma das falhas da ciência é pressupor que só se pode entender o mundo por meio dela. E eu realmente acho que as pessoas têm uma sede enorme de uma visão do mundo que vá além do que é simplesmente quantificável e mensurável.

Essa percepção é muito antiga. Ela remonta a quase todas as culturas humanas e a todas as formas de agrupamento de seres humanos neste planeta. É desnecessário lembrar diante de vocês, antropólogos, que é perigoso fazer generalizações sobre a consciência humana ou falar do pensamento indígena como se houvesse uma única cultura indígena porque havia - havia e há - milhares e milhares de culturas indígenas, todas diferentes. Mas eu acho que existe algo em comum entre elas que podemos identificar. Todas essas culturas têm algum tipo de relação com o que chamamos de espírito; algum tipo de relação com uma percepção e uma conexão emocional mais profunda com a vida e a Terra e a teia da vida do que o quantificável e o mensurável. Essa percepção tem bastante a ver com o que as culturas indígenas nos têm dito ao redor do mundo, se escutarmos quem faz parte delas e os movimentos políticos que iniciarem.

Tive neste ano o privilégio de passar um tempo em Standing Rock, na Dakota do Norte, no levante e protesto indígena contra o oleoduto que estava sendo colocado no território sagrado do povo Lakota de Standing Rock. Foi uma experiência muito poderosa estar em um espaço definido como indígena de forma tão consciente. Ao chegarmos lá, eles nos passavam uma série de instruções: "Vejam, nós adoramos música, música é algo lindo", diziam,

mas não queremos que vocês toquem guitarra nem cantem as músicas de vocês aqui. Queremos apenas as nossas músicas cantadas neste espaço. Nós adoramos espiritualidade e religião, e sabemos que vocês podem ter a espiritualidade e a religião de vocês, mas queremos que as únicas cerimônias realizadas aqui sejam nossas, porque somos os verdadeiros guardiões desta terra e estamos conectados com o espírito que lhe é próprio.

Como há décadas procuro mostrar às pessoas que espiritualidade e política caminham juntas, foi muito poderoso para mim estar em um lugar onde havia uma enorme faixa dizendo "Este é um lugar de cerimônia e oração". Um lugar onde cada ação - tudo que fazíamos, na verdade - era concebida e nomeada como cerimônia e oração ativa. Cada marcha era uma oração.

Tantas e tantas vezes em Standing Rock, tantas e tantas vezes em muitos outros lugares e em muitas outras lutas, ouvimos dizer que a Terra é sagrada, que a água é sagrada, que a água é vida. E quando marchávamos por Standing Rock, cantávamos assim: "Mni Wiconi”: a água é sagrada, a água é vida. Na Bolívia, por exemplo, nos levantes indígenas contra a privatização da água, foi redigida uma declaração dos direitos da água que dizia o seguinte: "A água é um direito humano e deve ser 
considerada sagrada”. Já no Equador, os movimentos políticos indígenas resultaram em uma Declaração dos Direitos da Natureza.

Acredito que podemos dizer com segurança que existem alguns valores fundamentais do mundo indígena que chegam até nós. São estes os valores de que precisamos para sair da bagunça em que nos encontramos. Vivemos em um mundo bastante moldado pela herança ocidental e pela herança europeia. É importante sabermos que esses valores fundamentais também estão presentes na história da Europa e do Oriente Médio, e entender o processo histórico pelo qual eles foram subjugados. Isso nos leva a adentrar o domínio da magia.

Sempre gostei do modo como Dion Fortune, uma ocultista do início do século XX, define magia: segundo ela, a magia seria "a arte de modificar a consciência de acordo com a vontade”. Essa definição inclui a arte e as ideias de visão e imaginação. Inclui também a ideia de mudança: implica que o mundo é dinâmico e fluido, e não estático. E ela fala de "vontade": uma intenção humana focada que tem um impacto no mundo em torno de nós.

Penso que essa também é uma boa definição para a ação política. Buscar mudanças políticas profundas não abrange apenas mudar quem detém o poder, embora isso seja bastante importante. Mas também implica o modo como concebemos o nosso poder e como mudamos a consciência que permitiu que tantos danos ocorressem e tivessem continuidade.

Ao considerarmos as raízes da história europeia e as descobertas da arqueologia, percebemos nas imagens das cavernas do Paleolítico um mundo cheio de vida, repleto de animais, espíritos e interação humana, além de honrar o princípio feminino do surgimento da vida no mundo. As cavernas são como o útero e o corpo da Deusa e da Mãe Terra. Pintadas com animais - touros e cavalos e leões incríveis - muitas vezes se encontravam em locais acessíveis apenas por passagens estreitas, como se conduzissem a uma volta ao útero. Podemos imaginá-las iluminadas pelo fogo e pela luz, sendo pintadas em rituais, como um ato mágico. Era um ato de comunhão, de ligação entre o mundo humano e o mundo espiritual.

Uma das ideias indígenas fundamentais às quais me referi é a de que os seres humanos não são algo separado do resto do mundo, dos animais, das plantas, da vida, da espiritualidade: o que existe é um contínuo e um fluxo de consciência que atravessam o próprio mundo e a própria Terra. Os seres humanos fazem parte desse mundo natural.

Um dos palestrantes que se apresentaram hoje na ReACT falou de como os povos indígenas com os quais ele trabalha disseram a ele que toda a natureza canta. Isso é lindo. A natureza canta e fala, e o mundo inteiro se comunica conosco. Nisso podemos reconhecer outra definição de magia: a magia seria a arte de se abrir e ouvir profundamente essa comunicação. Essa sensibilidade é parte constituinte de milhares de culturas diferentes em toda a Europa e no Oriente Médio, muitas das quais se concentram na figura da Deusa. O maravilhoso trabalho da arqueóloga Marija Gimbutas chamou atenção para algumas dessas imagens e desenhos que ela encontrou por toda a Europa no período que chamou de Europa Antiga - do início do Neolítico até cerca de 3500 a.C. Foi nesse momento que ocorreu a transição das culturas de caça-coleta para o início da agricultura e todas essas coisas que 
nós gostamos de chamar de civilização: a cerâmica, a arquitetura, a tecelagem, a confecção de roupas e, a partir de determinado momento, a escrita. Havia culturas que honravam o fluxo da vida, considerando-o feminino e conectando-se integralmente com ele.

Gimbutas cresceu na Lituânia no início do século XX e se mudou para os Estados Unidos como refugiada após a Segunda Guerra Mundial. A Lituânia foi o último país da Europa a ser cristianizado, de modo que na década de I920, durante a infância de Gimbutas, ainda havia camponeses que preservavam alguns hábitos dessa velha religião, beijando o chão ao acordar a cada manhã, reverenciando e lançando leite para as cobras, colocando cercas em torno de árvores sagradas e lhes oferecendo oferendas.

Ainda hoje é possível encontrar reminiscências dessas antigas tradições de cura. Há lugares na Europa, por exemplo, onde ainda existem curandeiros tradicionais. No verão passado, dei aulas no País Basco, em um lugar que fica ao pé de uma montanha considerada sagrada pela Deusa do povo local. Lá ainda existe uma consciência bastante forte da antiga mitologia e do antigo panteão, centrados na Deusa e no seu consorte, no Sol e na Lua, nas polaridades da vida. Isso nunca foi deixado para trás.

Ao longo dos anos, houve muitas controvérsias entre os arqueólogos sobre se existiam ou não Deusas. No entanto, indo além da perspectiva que considera que apenas o que é material e quantificável é real, e se aproxima de uma visão do mundo que analisa as relações em jogo, percebemos que essas tradições, na verdade, nunca foram esquecidas de fato, mesmo na Europa.

O que aconteceu foi que nos séculos XVI e XVII houve uma tremenda reação contra tudo o que restava do Paganismo antigo, o que acabou motivando as perseguições às Bruxas. As pessoas geralmente pensam nas perseguições às Bruxas como próprias da era medieval, mas, na verdade, elas ocorreram bem mais tarde, tendo começado no final dos anos I400, com a publicação do Malleus Maleficarum por dois monges jesuítas, Kraemer e Sprenger, e de uma bula pontifícia do papa Inocêncio VIII que criminalizou a bruxaria, julgando-a um ato de heresia. A perseguição às Bruxas também se desenvolveu e se intensificou em muitos lugares por conta das ações das igrejas protestantes. Não foi à toa que a perseguição às Bruxas ocorreu ao mesmo tempo que a transição das antigas economias feudais para o capitalismo moderno se iniciava. Na verdade, foi a perseguição às Bruxas que preparou o terreno para o capitalismo.

Quero compartilhar com vocês um pouco do trabalho de um historiador da ciência maravilhoso chamado David Kubrin. Muitos anos atrás, quando eu estava escrevendo Dreaming the dark, no final dos anos I970, início dos anos I980, ele começou a falar de marxismo e feitiçaria, o que influenciou imensamente meu pensamento sobre esse período. Ele agora está preparando um novo livro sobre marxismo e feitiçaria, no qual diz o seguinte:

O mundo natural enfrentou um ataque sem precedentes com a conquista da América, logo estendida à África, Ásia etc., e com o surgimento do sistema capitalista em escala mundial por volta da mesma época. Fortunas foram feitas e impérios construídos graças a itens do domínio natural, que haviam sido tomados e vendidos. Metais 
preciosos ou minerais, árvores e peles, açúcar e rum e milhões de seres humanos escravizados foram levados para essas minas e plantações, todos cortados ou desenterrados e transformados em commodities, a prioridade ontológica máxima da nova ordem.

Assim, as perseguições às Bruxas surgiram como uma maneira de contestar e erradicar a antiga percepção de que o mundo está vivo e de que a vida é dotada de percepção e consciência - não necessariamente a mesma percepção ou consciência que a sua ou a minha, mas a vida tem uma presença e tem um ser. A vida está sempre falando conosco. Até o século XVI, mesmo na Europa, essa noção era bastante presente na vida e na realidade; por conta dessa consciência, tinha-se uma ideia restrita do que poderíamos fazer em relação ao mundo natural. Podemos ainda hoje encontrar reminiscências dessa consciência e das restrições que ela impõe. Lembro-me de estar na Escócia alguns anos atrás e ler uma matéria no jornal sobre um conflito em uma comunidade local, na qual as autoridades queriam abrir uma estrada, mas os moradores afetados não aceitavam, porque havia uma árvore de fadas no caminho. Era nessa árvore que as fadas viviam. Ninguém queria tocá-la nem estava disposto a cortá-la, pois tinham medo do que as fadas lhes fariam.

Essa consciência, portanto, nunca desapareceu. Permanece a ideia de que o espírito tem um domínio próprio, que permeia o mundo natural e o mundo humano, e que precisamos manter um relacionamento adequado com ele. Para fazê-lo, é preciso reverenciar e respeitar o mundo natural, devolvendo, oferecendo reciprocidade, e não simplesmente tirando, tirando, tirando. Essa sensibilidade se mostrava completamente contrária à nova sensibilidade do capitalismo, que consistia em extrair valor sem restrições. Ao mesmo tempo que surgiam as perseguições às Bruxas, desenrolava-se a Reforma, durante a qual ocorreu uma expressiva revolta contra a antiga igreja católica, bem como o surgimento da nova igreja protestante.

Simultaneamente, vinham à tona outras filosofias e concepções, muitas das quais se baseavam nas antigas ideias de que o mundo era permeado pela vida. Muitos desses grupos, como os Escavadores e os Niveladores, na Inglaterra, também se opunham radicalmente à ordem política.

As perseguições às Bruxas representaram uma reação a esse tipo de pensamento, considerando-o perigoso, mau, alinhado com o diabo. Quem o praticasse ou falasse a respeito dele, especialmente se fosse mulher - uma mulher independente, de posses, com poder ou algum status por ser curandeira ou parteira -, estaria em perigo. As perseguições, portanto, eram uma maneira de fazer frente ao entusiasmo - isto é, a um conjunto de filosofias que viam o mundo como repleto de vida e potencial de mudança.

Entre as classes mais altas, essas filosofias centradas na vida foram incorporadas à prática da alquimia e da magia cerimonial. Uma das coisas que David Kubrin diz é que Isaac Newton - um dos pais do racionalismo - era, em segredo, alquimista. Existe uma série de escritos que Newton não chegou a publicar em vida. Ele realmente acreditava que o mundo tinha vida, consciência e se comunicava conosco, mas havia muitas razões políticas pelas quais ele optou por aderir ao materialismo. Isso porque o entusiasmo - a ideia de que existe uma energia que permeia a vida e o próprio 
mundo como dinâmico e em constante mutação - acabou sendo relacionado a muitos desses grupos rebeldes que também enfrentavam a ordem social da época. Trata-se, em particular, de um entusiasmo que fazia frente à extração de dinheiro, valor e terra das classes camponesas e das classes trabalhadoras; que desafiava a concentração desse valor nas classes altas e em cada vez menos mãos - algo que ainda vemos acontecer hoje. Para Newton, portanto, a eliminação dessas ideias perigosas e mágicas e radicais de sua escrita - e do nascimento do que viria a se tornar a tradição científica - foi uma decisão política.

Para aqueles de nós que acreditam que a ciência é real e importante e que precisamos prestar atenção a ela em tempos de mudança climática, também é importante entender que o modo como compreendemos a ciência hoje é apenas uma parte do que o conhecimento humano poderia potencialmente englobar se nos permitíssemos retornar, resgatar e reativar alguns desses antigos conhecimentos e compreensões. A perseguição às Bruxas funcionou de forma semelhante à guerra ao terrorismo que ocorre atualmente nos Estados Unidos, como uma desculpa para impor violência e poder policial extremo sobre segmentos inteiros da população ao mesmo tempo que distrai o restante das pessoas, gerando um medo tremendo, que na verdade não tem conexão alguma com a realidade que de fato está colocando suas vidas em perigo. Ambas as situações projetam o foco para fora de si, dando a entender que é possível fazer frente ao sentimento de terror e dizer: "nós estamos protegendo vocês dessa coisa horrível”. Então, em relação à guerra ao terror, a verdade é que as chances reais de você ser uma vítima de um ataque terrorista são, de certa forma, menores do que as chances de você ser abduzido por um alienígena, de acordo com as estatísticas. No entanto, a realidade nos Estados Unidos é que vimos ao longo dos últimos dez anos uma transferência sem precedentes de riqueza e propriedade de pessoas pobres e de classe média para as mãos de I\%. Já se chamou a grande quebra de 2008 como a maior transferência de riqueza da comunidade negra para a comunidade branca desde a escravidão, pois muitas das pessoas que perderam suas casas, muitas das pessoas que haviam feito empréstimos imobiliários de alto risco eram negras, já que essas foram as pessoas relegadas a esse nível no mundo financeiro. Vimos a situação ecológica mais assustadora que o mundo já enfrentou com a mudança climática, uma ameaça absolutamente aterrorizante e real à civilização, à vida humana na Terra e a um enorme número de outras espécies. E percebemos o quão difícil é chamar a atenção das pessoas para isso. Ao mesmo tempo, é muito fácil fazê-las focar no medo de muçulmanos que podem imigrar e explodir algo nas cidades em que vivem. Trata-se de um grande truque de manipulação da mente.

Se retornarmos mais uma vez à perseguição às Bruxas, veremos que ela funcionou da mesma forma. Numa época em que os camponeses estavam vendo a delimitação dos bens comuns - a terra tradicionalmente disponível para todos - e a restrição dos direitos campesinos, em que a riqueza havia sido levada daqueles que trabalharam a terra e em que as oportunidades estavam diminuindo, quando um grande número de pessoas foram expulsas do campo e forçadas a ir para as cidades e trabalhar para receber pagamento, e uma época em que o conhecimento estava sendo mais e mais restringido, os governantes se beneficiaram e colocaram o foco nos medos das 
pessoas em relação àquela horrível e malvada bruxa, que poderia ser sua vizinha, em vez de colocar o foco em seu suserano, contra quem você poderia se rebelar.

Houve, entretanto, inúmeras rebeliões campesinas ao longo daquele período, milhares delas, na França, na Espanha, em toda a Europa e na Inglaterra. As pessoas que detinham o poder estavam preocupadas com a solidariedade campesina e de classe. Atacar as curandeiras tradicionais, fragmentar as comunidades e torturar pessoas até que denunciassem seus vizinhos eram formas poderosas de interromper essa solidariedade.

A perseguição às Bruxas foi parte da expropriação de terra, além de também ter sido uma expropriação de conhecimento. Ela deixou um legado que diz que apenas o conhecimento acordado entre as autoridades é real e aceitável. Ela representou ainda uma forma de expropriação da cura. O partejo, que sempre foi um conhecimento preservado pelas mulheres, agora se tornou suspeito, e médicos do gênero masculino se tornaram a autoridade final em relação a ele. As mulheres nunca deixaram de ser parteiras, mas deixaram de ser respeitadas e de ter poder. Uma parteira possui o poder da vida e da morte e isso era uma ameaça à Igreja, que queria ser o árbitro final em relação a esse poder. Assim, durante a Guerra dos Trinta Anos, houve um período em que, em Colônia, quase todas as parteiras foram mortas sob acusações de serem Bruxas, o que, como é possível imaginar, impactou imensamente a saúde das mulheres daquela cidade.

Os médicos, naquela época, em primeiro lugar não praticavam a higiene. Não lavavam suas mãos quando iam de um paciente a outro. Eles eram entusiastas de hábitos como fazer sangria com sanguessugas nas pessoas de acordo com os pontos astrológicos de cada um, e sua medicina formal tendia a ser, com bastante frequência, destrutiva e dolorida, algo como o tipo heroico de medicina alopata praticado atualmente, mas menos efetivo. As curandeiras tradicionais, no entanto, usavam ervas, muitas das quais nos deram remédios que usamos até hoje - de aspirina a dedaleira. Muitas das ervas e dos remédios que usamos vieram, na verdade, da prática das parteiras e das curandeiras.

A perseguição às Bruxas nos deixou um legado que cortou nossa sensibilidade em relação a uma Terra viva. É difícil para a gente se abrir e escutar a Terra falando sem sentir medo ou sem, ao menos, sentir que estamos fazendo algo suspeito e perigoso ou talvez apenas algo ridículo, algo que obviamente não é verdadeiro. Eu frequentemente reflito sobre como seria ter uma ciência que admitisse a possibilidade de consciência. Como seríamos se nos permitíssemos abraçar novamente algumas das visões de mundo indígenas e, ao mesmo tempo, somar a elas alguns dos nossos modos atuais de entender como comprovar rigorosamente nosso conhecimento.

Eu gosto de escrever ficção, entre outras coisas, e gostaria de ler um pequeno trecho para vocês. É do meu livro mais recente, City of refuge, que ainda não foi traduzido para o português, mas é uma continuação, é uma sequência de Fifth sacred thing [A quintessência sagrada, em português]. E Fifth sacred thing é centrado em torno da questão "Como uma sociedade pacífica se defende quando se depara com a violência?". É ambientado na Califórnia, em meados do século XXI, quando o Norte da Califórnia se torna um lugar ecotópico, diverso, bonito e equilibrado, mas o sul da Califórnia se degenera em um país racista, militarista, bastante dividido e com pouquíssimos recursos. Trata-se do que acontece quando as terras do sul invadem o 
norte - ou, mais precisamente, do que acontece quando as terras do norte decidem que precisam liberar as terras do sul. A questão central é: "Como construímos o novo mundo quando as pessoas estão tão profundamente feridas pelo velho?”. Em determinada cena, os techies decidem hackear o sistema das terras do sul, mas eles trabalham com a tecnologia de uma forma diferente. Seus computadores e internet são todos baseados em cristais inteligentes, que colaboram e se comunicam com eles. Segue, portanto, um pouco de sua jornada tecnológica:

Os feixes de luz se irradiavam de uma esfera luminosa, pulsante. Cress podia escutá-los, como as harmônicas de uma tigela de cristal, pulsando em ritmos que começaram a formar música. Eles viajaram em direção à esfera, e o tom se dividiu em linhas de som, em notas sendo tecidas umas em torno das outras e se fundindo em cordas. A esfera estava cantando para ele. Música. A músicas das esferas, como os antigos a chamavam.

Se quisermos lidar com a imensa crise decorrente da mudança climática e com sua grande crise irmã, a de grande concentração de riqueza e poder em cada vez menos mãos, precisaremos retornar a essa mágica sensibilidade indígena, admiti-la em nossas consciências e em nosso modo de pensar e de falar. Gostaria de descrever alguns dos pontos que considero verdadeiramente importantes para a compreensão dessa visão de mundo.

O primeiro é que essa visão de mundo é relacional. Seu centro principal é a compreensão de que tudo está interconectado e de que estamos sempre nos relacionando; não somos objetos separados e isolados. Não estamos vivendo no universo mecânico de Newton, em que tudo funciona por meio de causa e efeito, como a engrenagem de uma máquina. A visão de mundo relacional é muito mais próxima do que a ciência está nos dizendo atualmente, com relatividade e teoria de sistemas e com ciências como ecologia, que olha para os sistemas, e psicologia, que agora considera mais os sistemas de família, e não apenas a psique individual isolada.

Sempre estamos nos relacionando e precisamos entender o mundo como sendo composto de parentes. Os Lakota frequentemente dizem "Mitakuye Oyasin", "por todas as nossas relações", para declarar que somos parentes dos animais, das plantas, de tudo o que existe no mundo.

O segundo ponto-chave que precisamos compreender é que a Natureza é sagrada. Sagrada não no sentido de algo externo a que nos curvamos, mas no sentido de que é o que existe de mais importante, de que é o que estabelece os valores para todo o restante. Vou ler um outro pequeno trecho para vocês. Esta é a "Declaração das quatro coisas sagradas”, que é o prefácio de Fifth sacred thing. Ela diz:

Dizer que essas coisas são sagradas equivale a dizer que elas têm um valor para além de sua utilidade para fins humanos. É dizer que elas próprias se tornam a base a partir da qual nossos atos, nossa economia, nossas leis e nossos propósitos devem ser julgados. Ninguém tem o direito de se apropriar delas ou de lucrar a partir delas em detrimento de outros. Qualquer governo que falhe em protegê-las perde sua legitimidade. Honrar o sagrado é criar condições nas quais a nutrição, o sustento, o habitat, o conhecimento, a liberdade e a beleza possam vicejar. Honrar o sagrado é tornar o amor possível. 
O sagrado é a aquilo com o que nos importamos o suficiente para lutar e correr riscos. Não queremos vê-lo destruído ou danificado. Compreendemos que ele é a base das coisas que realmente sustentam a vida.

Para nos opormos verdadeiramente à mudança climática, precisamos não apenas de estatísticas relativas ao carbono e ao metano. Precisamos compreender que há valores que estão além do lucro e da extração. Quando abraçamos esses valores, também recebemos de volta o imenso valor da nossa conexão intuitiva com a natureza, das formas por meio das quais a natureza se comunica e fala conosco.

Esse mundo interconectado e sagrado tem uma qualidade integradora, tudo nele tem seu próprio valor intrínseco. É um mundo em que humanos, animais, plantas, consciência, espírito desaguam uns nos outros. Nós não vemos separações profundas entre o humano e o animal, entre o interno e o externo. Nós não separamos as pessoas como se algumas tivessem valor e outras não. O sagrado é imanente a todos.

Em um mundo interdependente, somos mutuamente responsáveis uns pelos outros como seres humanos. Não dizemos "meu privilégio é separado do seu privilégio e eu tenho o direito de privilegiar o meu à custa do seu". Compreendemos que todos nós estamos juntos na mesma teia e que temos a responsabilidade e o dever de cuidar uns dos outros.

Esses valores centrais também permeiam muitas tradições religiosas e culturas que não são indígenas. Eles são os valores que podem realmente nos ajudar a enfrentar as crises gêmeas: a ecológica e a social. Portanto, vou apenas dizer algumas poucas palavras a respeito de como é colocar essa sensibilidade em prática.

Dentre outras coisas, eu ensino permacultura. A permacultura é um sistema de design ecológico que surgiu na Austrália nos anos I970. O termo foi cunhado por um professor de estudos ambientais, Bill Mollison, da Universidade da Tasmânia, e por seu aluno de pós-graduação David Holmgren. Eles estavam observando as florestas da Tasmânia, antigas florestas tropicais, e comentando:

Ninguém precisa vir a essas florestas para fertilizá-las ou borrifar nelas produtos contra insetos. Ninguém está podando essas árvores. Ainda assim, este é um dos ecossistemas mais produtivos e saudáveis da Terra. Seria possível plantar alimentos para seres humanos da mesma forma que a floresta cresce por si só? Se observássemos a natureza e nos modelássemos de acordo com a forma por meio da qual ela faz todas as coisas, poderíamos realmente suprir nossas necessidades humanas de maneira que o mundo natural em torno de nós fosse regenerado em vez de destruído?

Esse questionamento motivou o surgimento de um conjunto de princípios éticos que poderiam ser facilmente os mesmos da tradição da Deusa ou de qualquer cultura indígena. São eles: “Cuide da Terra, cuide das pessoas, cuide das próximas gerações obtendo apenas o necessário e o justo; não use o mundo de forma exagerada nem devolva a ele seus excessos". Juntamente com os princípios éticos, surge uma série de procedimentos que nos ajuda a desenhar sistemas que supram nossas necessidades - de comida e abrigo e até de entretenimento - ao mesmo tempo que regeneram o ambiente natural ao nosso redor.

Com o passar do tempo, a permacultura se tornou um movimento global de 
pessoas que estão tentando colocar em prática um modo relacional de ser com a Terra. Ela se expandiu das práticas apenas agricultoras e gerou muitos tipos diferentes de sistemas humanos. Existe todo um campo de permacultura social que foi desenvolvido primeiramente por mulheres que eram parte do movimento. Esse campo trata da seguinte questão: "De que forma olhamos para as maneiras pelas quais nos organizamos juntos, como seres humanos, e encontramos modos de pensar nesses sistemas e torná-los mais efetivos?”.

De um ponto de vista permacultor, se olharmos para a questão da mudança climática por meio das lentes dos sistemas, veremos que ela representa uma imensa disfunção global do ecossistema, resultante da massiva disfunção global econômica e social. A partir dessa perspectiva, a resposta à mudança climática deve ser uma grande regeneração do ecossistema que englobe também uma grande regeneração do sistema social.

Quero ler para vocês um pequeno fragmento de uma declaração relativa à mudança climática que publicamos na Convergência Internacional de Permacultura em 20I5, em Londres. Mais de 600 pessoas de centenas de organizações diferentes ao redor do mundo assinaram essa declaração. Ela diz:

A mudança climática ocasionada por seres humanos é uma crise de sistemas - ecossistemas e sistemas sociais - e deve ser abordada sistemicamente. Novas tecnologias ou soluções generalizadoras não resolverão o problema. A permacultura emprega sistemas pensando, observando padrões, relações e fluxos, conectando soluções a estratégias sinérgicas que trabalham com a natureza e combinam condições locais, terreno e cultura. Ações para enfrentar a crise climática devem ser baseadas na justiça social, econômica e ecológica.

A partir daí, a declaração fala sobre quais são as soluções. As soluções são, novamente, como regeneramos as paisagens ao nosso redor e as paisagens internas e sociais. A boa notícia é que realmente podemos fazer isso. Há muitos e muitos exemplos de ambientes devastados que foram trazidos de volta à vida. Os chineses fizeram isso no planalto de Loess, terra que é o local original de nascimento do povo chinês. A área tem o tamanho da Bélgica e se tornou completamente desertificada. A partir dos anos I990, os chineses passaram por uma série de programas, utilizando muitas das técnicas sobre as quais falamos em permacultura, formas de esculpir a terra para reter e captar água, restringindo o sobrepastoreio, replantando gramíneas e árvores. Atualmente, a paisagem em questão, já regenerada, é verde e bonita.

Tony Rinaudo, que trabalha com a World Vision, na África, tem uma história dedicada a plantar árvores no Sahel, a área em direção à qual o Saara está avançando. Ele disse que ele e seus colegas passaram anos plantando árvores. Plantavam árvores e mais árvores, e as árvores morriam. Eles plantavam mais e mais árvores, e elas então morriam, e a desertificação ficava cada vez pior. Finalmente, um dia, enquanto olhava para o chão, desencorajado, viu pequenas partes de arbustos. E percebeu que na verdade eram árvores que haviam sido comidas e pastadas em demasia até serem reduzidas a nada além de arbustos bem pequeninos. Ele pensou: "E se em vez de plantarmos novas árvores, protegêssemos estas aqui?”. 
Ele desenvolveu um método muito simples de treinar os agricultores. Eles cercavam os arbustos de árvores para protegê-los dos bodes, podavam-nos até reduzi-los a um ou dois talos e os deixavam crescer. Em poucos meses, tinham árvores. Essas árvores criaram condições que permitiram que outras árvores crescessem. Eles hoje já reflorestaram milhões de hectares em Mali, no Níger e na Etiópia e cuidaram de lugares em que, em vez de a desertificação avançar, as pradarias, árvores e savanas estão na verdade recuperando o deserto. Isso mostra que uma iniciativa assim pode ser bem-sucedida.

Outra figura inspiradora é Allan Savory, do Zimbábue, que foi guarda-florestal. Ele foi biólogo especializado em vida selvagem e amava a fauna selvagem africana, mas a terra estava se degradando e os elefantes estavam perdendo seu habitat. Primeiramente eles pensaram que havia elefantes em demasia, e que isso desgastava as áreas de pasto. Eles na verdade abateram 40.000 elefantes. Ele disse que essa foi a pior experiência de toda a sua vida e que se arrependerá disso até o dia de sua morte. A terra ficou ainda mais degradada.

Em seguida, eles passaram a acreditar que o problema era a quantidade de pessoas que viviam naquela terra, então as removeram da reserva. Isso é algo que acontece com frequência em reservas biológicas. E a terra ficou ainda mais degradada.

Finalmente, ele percebeu que estavam fazendo as perguntas erradas. Eles estavam perguntando quantos animais havia em cada acre de terra, quando, em vez disso, deveriam estar perguntando como os animais estavam interagindo com as gramíneas e quanto tempo cada animal estava passando em cada pedaço da terra.

Ele percebeu, então, que os animais que se alimentam de gramíneas e as pradarias coevoluíam, e que as pradarias, na verdade, precisavam do impacto das manadas de animais e do fato de eles se alimentarem de gramíneas para deixar o solo batido, para diminuir a grama seca, para defecar e urinar em todo o canto e fertilizar o solo e, em seguida, partir para outro local, para que as gramíneas tivessem chance de se recuperar. As manadas agiam dessa forma na presença de predadores, porque os predadores faziam com que os animais se mantivessem juntos para se proteger e continuar se movimentando. Os seres humanos que estavam na reserva funcionavam como predadores, e removê-los piorou a situação.

Savory desenvolveu um sistema de pastagem que se espalhou por todo o mundo, chamado gerenciamento holístico de pastagem ou, às vezes, do que conhecemos como mob grazing. Utilizando esse sistema, vacas, gados e ovelhas, em vez de devastarem a terra, tornam-se agentes regeneradores.

Há muitos e muitos exemplos de como, quando mudamos nossa forma de pensar e nossa abordagem, temos a capacidade de funcionar como agentes de cura em vez de agentes de destruição. Considero isso importante porque, se vamos lidar com a mudança climática, precisamos oferecer esperança às pessoas. Não podemos dizer a elas, como costumamos fazer, "pois é, provavelmente estamos condenados e isso é culpa nossa”. Não é uma boa mensagem motivacional, certo? Acho que o que devemos dizer às pessoas é: "Sim, há esperança. Ainda é possível. Mesmo que tenhamos ultrapassado muitos pontos críticos, temos como contornar a situação, lançar o carbono para fora da atmosfera e regenerar o solo e a terra ao nosso redor".

E o modo pelo qual podemos fazer isso não envolve coisas horríveis, exploração, 
ações cruéis e sacrifício em massa. São, na verdade, coisas legais. Elas envolvem construir o solo, pois um solo vivo é uma ecologia. As plantas e o solo juntos têm uma capacidade imensa de lançar o carbono para fora da atmosfera, transformando-o em corpos de plantas, em vida para o solo, em carbono orgânico para o solo, o que aumenta a fertilidade do solo, a capacidade de reter água e o cultivo e a saúde das plantas. Os solos do mundo atual têm um grande déficit de carbono devido aos milhares de anos da agricultura e particularmente às últimas centenas de anos da agricultura industrial, e podemos pagar esse débito com excesso de carbono atmosférico.

É possível criarmos sistemas perenes e sistemas de alimentação e árvores. Podemos proteger as florestas vivas e as florestas tropicais que ainda temos, que são os imensos transformadores de carbono. Podemos curar e regenerar a terra que foi danificada e destruída. Temos a tecnologia adequada para fazermos a transição para formas seguras e renováveis de gerar energia. Não se trata de não dispormos dessa tecnologia. Nós já dispomos dela, e não só podemos como devemos empregá-la. Temos que deixar para trás os combustíveis fósseis. E quando fizermos isso - adivinhem? - vamos parar de gerar cicatrizes imensas e terríveis no planeta e cessaremos a destruição das comunidades indígenas em todos os lugares, do Equador, passando por Brasil e Colômbia, até chegar na África, cujas terras são os locais de que estão extraindo petróleo geralmente à custa do meio ambiente e das pessoas que vivem ali.

Precisamos retomar a ideia de comunidade. Precisamos situar novamente os locais onde produzimos as coisas, especialmente a comida, mas também a energia e os materiais e o que as pessoas necessitam, e basear as nossas iniciativas novamente na ideia de comunidade, em vez de pensar que podemos apenas ir de um lado para o outro do mundo, fugindo dos padrões de proteção ambiental e trabalhista. E precisamos compor uma comunidade para que nós, seres humanos, tenhamos senso de conexão, para que nossa satisfação se origine menos do ato de consumir e mais do fato de estarmos nos relacionando; para que, em vez de sermos ricos em quantidade de coisas, possamos ser ricos em tempo para nos conectar com nossos amigos e com nossa família e compartilhar cerimônias, histórias e refeições juntos, para fazer as coisas que alimentam nosso coração, nossa alma e nossa união. Se há uma palavra que é um antídoto para a mudança climática, essa palavra é comunidade.

Tudo isso é passível de ser feito. Tudo isso é possível de ser feito. Acredito que todos nós estejamos aqui agora neste momento porque temos um papel importante para cumprir. E a única coisa que está nos detendo é a organização política e econômica do mundo e sua estrutura de poder, que está determinada a mantê-la. Isso não é um problema, certo?

Precisamos de muitas e muitas formas de ativismo. Acredito que aqueles de vocês que estão desenvolvendo pesquisas, novos modos de pensar e de olhar para o mundo e nos dando um background acadêmico estão levando adiante uma forma importante de ativismo. Também necessitamos de todo o resto: desde manifestações nas ruas à ação direta e não violenta para dar um basta a algumas das coisas que vêm acontecendo. É especialmente necessário que apoiemos as comunidades indígenas em suas lutas pelos direitos sobre suas terras e águas no momento.

Porém, em relação a todo esse ativismo, acredito que somos mais efetivos quando 
conhecemos não apenas as coisas para as quais estamos dizendo "não", mas também aquelas às quais estamos dizendo "sim", quando temos visão em relação ao que queremos. Esse também é um ensinamento mágico que darei a vocês. O mundo é esse espaço fluido e dinâmico de energia. Essa energia pode ser direcionada por meio da vontade e da consciência humanas. E a vontade e a consciência humanas direcionam energia por meio de imagens que nos tocam e que são sensoriais, emocionais, mais do que apenas intelectuais, de acordo com algo que desejemos. Mas elas precisam ser imagens positivas. Não se pode fazer um feitiço de amor e dizer: "Não me mande outro relacionamento horroroso como esse do qual acabei de sair". Porque o que teremos em mente será esse relacionamento péssimo, e atrairemos outro bastante parecido. Alguns de vocês talvez já tenham passado por isso. Precisamos de uma imagem daquilo que desejamos. Um sentido emocional de estado afetivo do tipo de amor que desejamos.

O tempo está acabando. Vocês terão que descobrir isso por conta própria. Mas queria apenas dizer que acredito que com magia, com visão, com valores e com coragem, temos realmente o potencial de criar o mundo que desejamos. E acredito que, se passarmos por esse período desafiador, viveremos em um mundo mais bonito, mais equilibrado, mais justo, mais saudável e mais igualitário do que o mundo em que vivemos hoje.

SOBRE A AUTORA

STARHAWK é uma das escritoras neopagãs mais lidas no mundo. Ecofeminista, permaculturista e ativista antiglobalização, ela é professora do Earth Activist Training em Cazadero, Califórnia, Estados Unidos, e ministra cursos em diversos países.

E-mail:info@earthactivisttraining.org 